\title{
Isolation and Screening of Polyhydroxyalkanoates Producing Bacteria from Pulp, Paper, and Cardboard Industry Wastes
}

\author{
Anish Kumari Bhuwal, ${ }^{1}$ Gulab Singh, ${ }^{1}$ Neeraj Kumar Aggarwal, ${ }^{1}$ \\ Varsha Goyal, ${ }^{1}$ and Anita Yadav ${ }^{2}$ \\ ${ }^{1}$ Department of Microbiology, Kurukshetra University, Kurukshetra, Haryana 136119, India \\ ${ }^{2}$ Department of Biotechnology, Kurukshetra University, Kurukshetra 136119, India \\ Correspondence should be addressed to Neeraj Kumar Aggarwal; neerajkuk26@gmail.com
}

Received 26 May 2013; Revised 8 August 2013; Accepted 20 August 2013

Academic Editor: Ravin Narain

Copyright ( 2013 Anish Kumari Bhuwal et al. This is an open access article distributed under the Creative Commons Attribution License, which permits unrestricted use, distribution, and reproduction in any medium, provided the original work is properly cited.

\begin{abstract}
Background. Polyhydroxyalkanoates (PHAs) are storage materials that accumulate by various bacteria as energy and carbon reserve materials. They are biodegradable, environmentally friendly, and also biocompatible bioplastics. Unlike petrochemical-based plastics that take several decades to fully degrade, PHAs can be completely degraded within a year by variety of microorganisms into $\mathrm{CO}_{2}$ and water. In the present study, we aim to utilize pulp, paper, and cardboard industry sludge and waste water for the isolation and screening of polyhydroxyalkanoates (PHAs) accumulating bacteria and production of cost-effective PHB using cardboard industry waste water. Results. A total of 42 isolates showed black-blue coloration when stained with Sudan black B, a preliminary screening agent for lipophilic compounds, and a total of 15 isolates showed positive result with Nile blue A staining, a more specific dye for PHA granules. The isolates NAP11 and NAC1 showed maximum PHA production 79.27\% and 77.63\% with polymer concentration of $5.236 \mathrm{~g} / \mathrm{L}$ and $4.042 \mathrm{~g} / \mathrm{L}$ with cardboard industry waste water. Both of the selected isolates, NAP11 and NAC1, were classified up to genus level by studying their morphological and biochemical characteristics and were found to be Enterococcus sp., Brevundimonas sp. and, respectively. Conclusion. The isolates Enterococcus sp. NAP11 and Brevundimonas sp. NAC1 can be considered as good candidates for industrial production of PHB from cardboard industry waste water. We are reporting for the first time the use of cardboard industry waste water as a cultivation medium for the PHB production.
\end{abstract}

\section{Introduction}

Plastic materials that have been universally used in our daily lives are now causing serious environmental problems. Millions of tons of these nondegradable plastics accumulate in the environment per year. For efficient management of used-plastic materials, recycling is one solution. Another solution to reduce plastic residue is the use of biodegradable plastics $[1,2]$ and among them polyhydroxyalkanoic acids (PHAs) are drawing much attention. Polyhydroxyalkanoic acids (PHAs) are common intracellular compounds found in bacteria, archaea, and in few eukaryotes such as yeasts and fungi. PHAs are carbon and energy reserve polymers produced in some microorganisms when carbon source is in plentiful and other nutrients such as nitrogen, phosphorus, oxygen or sulfur are limited. PHAs are found to accumulate in varieties of microorganisms as reserve food material for example, Alcaligenes latus, Ralstonia eutropha, Azotobacter beijerinckii, Bacillus megaterium, and Pseudomonas oleovorans, including some fungi and archaea. Among the members of PHA family, polyhydroxybutyrate (PHB) is the most common biodegradable polymer and promising alternative to synthetic nondegradable plastics. These polymers are accumulated intracellular membrane enclosed inclusion up to $90 \%$ of the cell dry weight under conditions of nutrient stress and act as energy reserve material. It has similar mechanical properties as those of the oil-derived conventional plastics like polypropylene or polyethylene which can be molded, made into films, spun into monofilaments, and used to make heteropolymers with other synthetic polymers and many more applications in agriculture, packaging, and medical field being biodegradable and also immunologically compatible 
with human tissue [3]. Recently, another application of PHAs is reported as biofuel [4].

In spite of these interesting properties, industrial production of PHAs is still not well established. In the 1950s, North-American Company W.R. Grace Co. made the first attempt to produce PHB at commercial level. However, this process was not successful due to low production efficiency and a lack of suitable purification method. Then, in the 1970s, Imperial Chemical Industries (ICI, UK) started producing PHAs by using a mutant stain Cupriavidus necator, NCIB 11599 from various carbon sources such as 1,4butanediol, 1,6-hexanediol, and butyrolactone. The commercial product was recognized as Biopol. The patents were later sold to Zeneca, then to Monsanto and are currently the property of Metabolix, Inc. (USA). Commercially, some other biopolyester products with different monomer composition are also produced with trade names such as poly(3HB-co-3HV) Nodax, poly(3-hydroxybutyrate-co3-hydroxyalkanoate) poly(3HB-co-3HA) as Biogreen, and poly $(3 \mathrm{HB})$ as Biomer [5]. But the large scale production was halted at commercial level due to the high production cost as compared with the oil-derived plastics $[1,6]$. With the aim of commercializing PHA, great efforts have been employed to reduce the production cost by the development of bacterial strains and more efficient fermentation/recovery process [7, 8]. From the literature, it has been found that the major cost in this biopolymer production is the cost of the substrate $[9,10]$ which accounts for more than $50 \%$ of production cost $[5,11]$ and makes the difference in price of poly-3hydroxybutyrate (P3HB) from Biomer about 12 times the cost of polypropylene [12]. To solve this problem, inexpensive substrate, renewable substrates, waste material, and waste water are used as nutrient source for microorganisms for PHA production. Various types of waste products have been used for PHB production because it provides dual benefits of utilizing the waste and cost-effective production of biodegradable microbial bioplastic.

Cardboard industry is one of the parts of pulp, paper, and packaging industry. Cardboard industry includes two main industries corrugated cardboard industry and noncorrugated cardboard or paper-board industry. Waste water from chemical and mechanical pulping contains $12-25 \mathrm{~kg}$ of $\mathrm{BOD} / \mathrm{t}$ of ADP, but the BOD discharges are 3 to 10 times higher in chemimechanical pulping as compared to mechanical pulping. Nitrogen and phosphorus are also present in waste waters and released from the pulping process of raw material such as wood, agricultural waste, and paper waste. Waste waters released from pulp and paperboard mills are typically rich in carbohydrates but poor in fixed nitrogen. If we consider the scenario of India, pulp and paperboard industry around 905.8 million $\mathrm{m}^{3}$ of water is consumed and around 695.7 million $\mathrm{m}^{3}$ of waste water is discharged annually. The largest part of the fresh water is used in sheet formation on the cardboard machine $\left(200 \mathrm{~m}^{3} \mathrm{~h}^{-1}\right)$ and the smallest quantity is used in stock preparation $\left(90 \mathrm{~m}^{3} \mathrm{~h}^{-1}\right.$ for thickening). Furthermore, the treatment of waste stream to purified effluent needs much effort and is very difficult, because the waste stream often contains various organic compounds. So instead of costly treatment, we can exploit the waste water directly for cultivation of PHB accumulating microorganisms. In this study, polyhydroxyalkanoic acids (PHAs) accumulating bacterial strains were isolated and screened using cardboard industry waste water as a sole carbon source with dual benefit of utilizing the waste and cost-effective production of biodegradable microbial bioplastic.

\section{Material and Methods}

2.1. Isolation of Polyhydroxyalkanoic Acids (PHAs) Producing Bacteria. For the isolation of PHA producing bacteriam activated sludge and waste water were collected from pulp, kraft, and cardboard manufacturing industry from Khanna pulp and paper mills at Amritsar and Topara Kurdh, Yamuna Nagar, India, respectively. The samples were stored at room temperature until analysis. In $99 \mathrm{~mL}$ sterilized water, $1 \mathrm{gm}$ of sludge sample was dissolved. Then, the sample was serially diluted in sterile distilled water and followed by plating on the nutrient agar medium with $1 \%$ glucose. For isolation from waste water sample, $1 \mathrm{~mL}$ of water sample was added in $99 \mathrm{~mL}$ sterilized water. After serial dilution $\left(10^{-3}\right.$ to $\left.10^{-7}\right)$, $1 \mathrm{~mL}$ of each dilution was spread on carbon rich nutrient agar plate. For the rapid detection and isolation of PHB producing bacteria, $0.02 \%$ alcoholic solution of Sudan black $\mathrm{B}$ was applied to stain bacterial colonies and the plates were kept undisturbed for $30 \mathrm{~min}$. The excess dye was then decanted and plates were rinsed gently by adding $100 \%$ ethanol. Colonies unable to incorporate the Sudan black B appeared white, while $\mathrm{PHB}$ producers appeared bluish black [13].

2.2. Screening for PHA Producing Bacteria. Sudan black B positive isolates were checked for PHA production by Nile blue A staining, a more specific stain for Polyhydroxyalkanoic acids (PHAs) by a more rapid and sensitive, viable colony method [14]. This dye at concentrations of only $0.5 \mu \mathrm{g} / \mathrm{mL}$ was directly included in carbon rich nutrient agar medium (glucose $1 \%$, beef extract $0.3 \%$, peptone $0.5 \%$, sodium chloride $0.8 \%$, and agar $1.5 \%$ ) and growth of the cells occurred in the presence of the dye. This allowed an estimation of the presence of PHAs in viable colonies at any time during the growth experiment and a powerful discrimination between PHA-negative and PHA-positive strains. The PHA accumulating colonies, after Nile blue A staining, showed bright orange fluorescence on irradiation with UV light and their fluorescence intensity increased with the increase in PHA content of the bacterial cells. The isolates which showed bright orange fluorescence on irradiation with UV light after Nile blue A staining were selected as PHA accumulators.

2.3. Pretreatment of Cardboard Industry Waste Water. Untreated cardboard industry effluent was collected from the cardboard industry, Topara Kurdh, Yamuna Nagar, Haryana, India, and stored at $4^{\circ} \mathrm{C}$ until used for analysis. The effluent was first filtered through the muslin cloth and then by rough filter paper to remove the undesired suspended solid materials from waste water. After this pretreatment step, 
cardboard industry waste water was used as quantification and production medium for PHA production by selected bacteria.

2.4. Extraction and Quantitative Analysis of PHA. The PHB production was observed in $250 \mathrm{~mL}$ Erlenmeyer flask containing $50 \mathrm{~mL}$ of treated cardboard industry waste water, as production medium under stationary conditions of growth. After $72 \mathrm{~h}$ of incubation at $37^{\circ} \mathrm{C}$, culture broth was centrifuged at $8000 \mathrm{rpm}$ for $15 \mathrm{~min}$. The pellet along with $10 \mathrm{~mL}$ sodium hypochlorite was incubated at $50^{\circ} \mathrm{C}$ for $1 \mathrm{~h}$ for lyses of cells. The cell extract obtained was centrifuged at $12000 \mathrm{rpm}$ for $30 \mathrm{~min}$ and then washed sequentially with distilled water, acetone, and absolute ethanol. After washing, the pellet was dissolved in $10 \mathrm{~mL}$ chloroform (AR grade) and incubated overnight at $50^{\circ} \mathrm{C}$ and was evaporated at room temperature [15]. After evaporation, $10 \mathrm{~mL}$ of sulphuric acid was added to it and placed in water bath for $10 \mathrm{~min}$ at $100^{\circ} \mathrm{C}$. This converts polyhydroxyalkanoic acids (PHAs) into crotonic acid, which gives maximum absorbance at $235 \mathrm{~nm}[16,17]$. PHB (Sigma Aldrich) was used as standard for making standard curve. For quantitative analysis of PHA, cell culture was grown as described earlier and cell pellet was dried to estimate the dry cell weight (DCW) in units of g/L [18]. Residual biomass was estimated as the difference between dry cell weight and dry weight of extracted PHA [19]. This was calculated to determine the cellular weight and accumulation other than PHAs. The percentage of intracellular PHA accumulation is estimated as the percentage composition of PHA present in the dry cell weight:

Residual biomass (g/L)

$=\operatorname{DCW}(\mathrm{g} / \mathrm{L})-$ Dry weight of extracted PHA $(\mathrm{g} / \mathrm{L})$,

PHA accumulation (\%)

= Dry weight of extracted PHA $(\mathrm{g} / \mathrm{L})$

$\times 100 \% / \mathrm{DCW}(\mathrm{g} / \mathrm{L})$.

2.5. Morphological Characterization and Biochemical Identification of PHA Producing Bacteria. Microscope Stereo Olympus was used to observe the morphology of bacterial colonies grown on nutrient agar. The growth characteristics such as structure, shape, color, margin, surface characteristics, surface upwards, smell, elevation, opacity, end of cells, cell's arrangement, and Gram-staining of the bacterial colonies were observed to characterize the bacterial colonies.

Various biochemical tests were performed in selected PHB producing bacteria, namely, indole production test, methyl red and Voges-Proskauer, citrate utilization test, and $\mathrm{H}_{2} \mathrm{~S}$ production for their biochemical characterization. The fermentative utilization of various carbohydrates was also followed for $48 \mathrm{hrs}$ at $37^{\circ} \mathrm{C}$ by inoculating the isolates separately in the defined medium to which various sugars like xylose, mannose, maltose, sucrose, raffinose, dextrose, trehalose, fructose, glucose, ribose, lactose, rhamnose, esculin, inulin, mannitol, arabinose, sorbitol, and melibiose were added.

\subsection{Polymer Analysis}

2.6.1. ${ }^{1} H$-NMR Spectroscopy and Thermal Gravimetric Anal$y$ sis (TGA). The identity of individual monomer unit was confirmed by proton nuclear magnetic resonance ( $\left.{ }^{1} \mathrm{H}-\mathrm{NMR}\right)$ spectroscopy. ${ }^{1} \mathrm{H}-\mathrm{NMR}$ spectra were acquired by dissolving the polymer in deuterochloroform $\left(\mathrm{CDCl}_{3}\right)$ at a concentration of $10 \mathrm{mg} / \mathrm{mL}$ and analyzed on a Bruker Avance II 500 spectrometer at $22^{\circ} \mathrm{C}$ with $7.4 \mathrm{~ms}$ pulse width $\left(30^{\circ}\right.$ pulse angle), $1 \mathrm{~s}$ pulse repetition, $10,330 \mathrm{~Hz}$ spectral width, and 65,536 data points. Tetramethylsilane was used as an internal shift standard. Thermal gravimetric analysis (TGA) was performed using a TGA instrument (Mettler-Toledo, TGA/SDTA 851, USA) calibrated with indium. The temperature was ramped at a heating rate of $10^{\circ} \mathrm{C} / \mathrm{min}$ under nitrogen to a temperature $\left(700^{\circ} \mathrm{C}\right)$ well above the degradation temperature of the polymers.

2.7. FT-IR Analysis. FT-IR analysis of the polymer sample was carried out on MB-3000, ABB FTIR spectrophotometer in the range $4000-600 \mathrm{~cm}^{-1}$.

2.8. GC-MS Analysis. Purified polymer, prepared as described before, was dissolved in $2 \mathrm{~mL}$ of chloroform and then $2 \mathrm{~mL}$ of methanol was added and acidified with $3 \%(\mathrm{v} / \mathrm{v})$ $\mathrm{H}_{2} \mathrm{SO}_{4}$ and heated at $100^{\circ} \mathrm{C}$ for $3.5 \mathrm{~h}$ for depolymerization and methanolysis of polyesters and $3 \mu \mathrm{L}$ was injected into GCMSQP 2010 Plus model. The samples were injected in the splitless mode and the injection temperature was $260^{\circ} \mathrm{C}$ and column oven temperature was $100^{\circ} \mathrm{C}$.

\section{Result and Discussion}

3.1. Isolation and Selection of PHA Producing Bacteria. A wide variety of bacteria are known to accumulate PHA. Today, approximately 150 different hydroxyalkanoic acids are known to be incorporated into polyhydroxyalkanoates [20], with microbial species from over 90 genera being reported to accumulate these polyesters [21]. These bacteria have been reported from various environments, but only a few from the waste water and sludge ecosystems. For the rapid detection and isolation of $\mathrm{PHB}$ producing bacteria, $0.02 \%$ alcoholic solution of Sudan black B and Nile blue A staining viable colony method [14] was used. The isolation of PHA producing bacteria was done from cardboard manufacturing industry waste water and pulp cardboard and kraft industry sludge. A large proportion about $35 \%$ of isolated bacteria produced PHA as energy reserve material. A total of 42 isolates showed black-blue coloration when stained with Sudan black B, a preliminary screening agent for lipophilic compounds, and a total of 15 isolates showed positive result with Nile blue A staining (Figure 1), a specific dye for the of PHA granules. Both gram-positive and gram-negative bacteria showed PHA production, but gram-positive bacteria dominated the waste material microflora of pulp, kraft, and cardboard manufacturing industry. Teeka et al. [22] used this method to screen the potential PHA producing bacteria from soil, and Ramachandran and Abdullah [23] also observed 




(a)

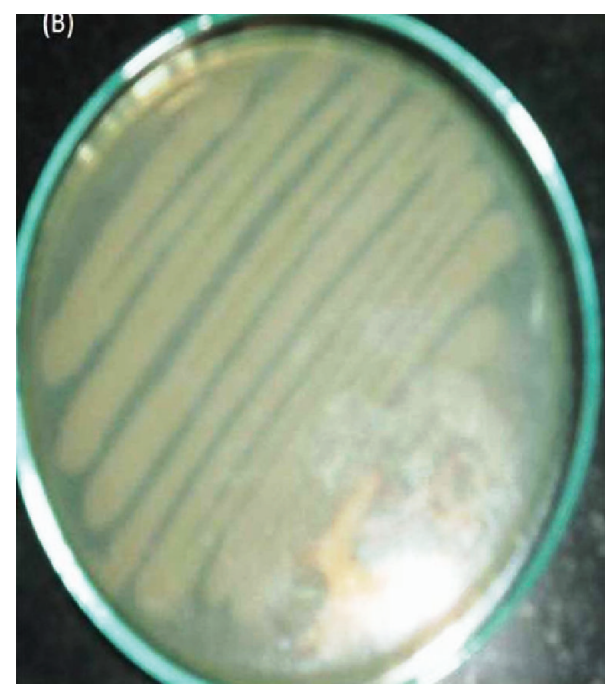

(b)

FIgURE 1: (a) Pink/orange florescence under UV light by PHB producer isolate NAP11. (b) No florescence under UV light by NonPHB producer with Nile blue A staining by viable colony method.

the colonies formed on nutrient rich medium under ultraviolet light (UV) to screen for the pink fluorescence which indicated the presence of PHA producers. Kitamura and Doi [24] first demonstrated this viable colony method on agar plates; they induced the isolates to accumulate PHA by culturing in $\mathrm{E}_{2}$ medium containing $2 \%(\mathrm{w} / \mathrm{v})$ glucose before Nile blue A staining. The PHA accumulating colonies, after Nile blue A staining, showed bright orange fluorescence on irradiation with UV-light and their fluorescence intensity increased with increase in PHA content of the bacterial cells.

\subsection{Production, Extraction, and Estimation of PHA with} Cardboard Industry Waste Water as a Sole Carbon Source. The PHA-positive isolates selected after Nile blue A staining were grown in $50 \mathrm{~mL}$ cardboard industry waste water in Erlenmeyer flasks and were employed to extract PHA after
2 days of incubation under stationary conditions of growth. The PHA from the isolates was extracted by the hypochlorite and chloroform method [15] as described earlier. The isolates NAP11 and NAC1 showed maximum PHA production $79.27 \%$ and $77.63 \%$ (Table 1) with cardboard industry waste water and were selected for further biochemical identification and chemical characterization.

Organic matter from wastes and waste waters has high BOD and COD values, and hence microorganisms can grow, utilizing the nutrient present in waste water, and can convert them into valuable compounds and polymers. Based on this idea, many researchers reported the PHA production from various industrial waste materials. PHA production by $A$. vinelandii from swine waste liquor was studied by [25]. The raw liquor supported the production of only $0.43 \mathrm{~g} / \mathrm{L}$ PHA, at a polymer content of $37 \% \mathrm{w} / \mathrm{w}$, whereas twofold dilution and supplementation with $30 \mathrm{~g}$ glucose/L allowed a PHA concentration of $5.5 \mathrm{~g} / \mathrm{L}$ at a $58.3 \% \mathrm{w} / \mathrm{w}$ polymer content. Few researchers have proposed coupling PHA production to biological waste water treatment [26-28]. Ceyhan and Ozdemir [29] reported polyhydroxybutyrate (PHB) production from domestic waste water using Enterobacter aerogenes $12 \mathrm{Bi}$ strain with good yield ranging from 16.66 to $96.25 \%$ $(\mathrm{w} / \mathrm{w})$. The use of pure C. necator cultures to produce PHAs from waste waters has been explored by Ganzeveld et al. [30]. They used a supernatant, obtained by centrifuging fermented organic waste, as the sole carbon source for the production of $\mathrm{P}(3 \mathrm{HBco}-3 \mathrm{HV})$, and obtained a maximum polymer concentration of $1.13 \mathrm{~g} / \mathrm{L}$ at a polymer content of $40.8 \%$ in $45 \mathrm{~h}$. Cardboard industry waste water is typically rich in carbohydrates but poor in fixed nitrogen, due to the high $\mathrm{C} / \mathrm{N}$ ratio. This high carbon-nitrogen ratio favors the growth of PHA producing bacteria. It is the first time that cardboard industry waste water is used for the isolation, screening, and production of polyhydroxyalkanoates. This waste has high BOD and COD values $680-1250 \mathrm{mg} / \mathrm{L}$ and $3400-5780 \mathrm{mg} / \mathrm{L}$ and COD/BOD ratio between 3.9 and 5 [31], which is suitable for microbial growth.

Extracted PHA of selected isolates was quantified and its efficiencies were compared with the standard. Standard pure culture of Ralstonia eutrophus MTCC no. 1473 was used for PHA production with cardboard waste water producing a polymer concentration of $2.974 \mathrm{~g} / \mathrm{L}$ and $\mathrm{PHB}$ content up to $41.30 \%$ with cardboard industry waste water. The selected isolates NAP11 from pulp sludge have produced $79.27 \%$ w/w PHA with polymer concentration of $5.236 \mathrm{~g} / \mathrm{L}$ using cardboard waste water which are $37 \%$ higher as compared to standard stain of Ralstonia eutrophus (Figure 2). The other NAC1 isolates showed PHA production up to $77.63 \%$ with polymer concentration of $4.042 \mathrm{~g} / \mathrm{L}$ under stationary conditions of growth.

3.3. Morphological and Biochemical Characterization of Selected Isolates. By using Bergey's Manual of Determinative Bacteriology [32] and by ABIS Online-Advanced Bacterial Identification Software, bothisolates were classified up to genus level using the morphological and biochemical characteristics (Table 2). NAP11 and NAC1 were found to be 
TABLE 1: List of PHA accumulating bacteria with source of isolation.

\begin{tabular}{|c|c|c|c|c|}
\hline Name of isolate & Source of isolate & $\begin{array}{c}\text { Gram } \\
\text { reaction }\end{array}$ & $\begin{array}{c}\text { PHA concentration } \\
(\mathrm{g} / \mathrm{L})\end{array}$ & PHA content $(\%)$ \\
\hline NAP11 & Pulp industry sludge & + ve & 5.236 & $79.27 \pm 0.3$ \\
\hline NAP4 & Pulp industry sludge & $+\mathrm{ve}$ & 3.682 & $65.75 \pm 0.2$ \\
\hline NAW2 & Waste water from cardboard manufacturing industry & $-\mathrm{ve}$ & 4.012 & $76.26 \pm 0.26$ \\
\hline NAW24 & Waste water from cardboard manufacturing industry & $+\mathrm{ve}$ & 4.018 & $62.90625 \pm 0.11$ \\
\hline NAW19 & Waste water from cardboard manufacturing industry & $+\mathrm{ve}$ & 3.824 & $59.52 \pm 0.34$ \\
\hline NAW23 & Waste water from cardboard manufacturing industry & $+\mathrm{ve}$ & 3.63 & $58.54839 \pm 0.27$ \\
\hline NAW27 & Waste water from cardboard manufacturing industry & $-\mathrm{ve}$ & 2.966 & $51.13793 \pm 0.16$ \\
\hline NAW34 & Waste water from cardboard manufacturing industry & $+\mathrm{ve}$ & 1.61 & $40.25 \pm 0.18$ \\
\hline $\mathrm{NAC1}$ & Waste sludge from cardboard manufacturing industry & $-\mathrm{ve}$ & 4.042 & $77.63 \pm 0.3$ \\
\hline NAC24 & Waste sludge from cardboard manufacturing industry & $+\mathrm{ve}$ & 4.006 & $65.75 \pm 0.12$ \\
\hline NAC10 & Waste sludge from cardboard manufacturing industry & $-\mathrm{ve}$ & 3.97 & $64.80 \pm 0.16$ \\
\hline NAC9 & Waste sludge from cardboard manufacturing industry & + ve & 3.802 & $70.92 \pm 0.13$ \\
\hline $\mathrm{NAC12}$ & Waste sludge from cardboard manufacturing industry & $+\mathrm{ve}$ & 3.682 & $68.28 \pm 0.04$ \\
\hline NAK8 & Kraft industry sludge & $+\mathrm{ve}$ & 3.83 & $71.53571 \pm 0.05$ \\
\hline NAK31 & Kraft industry sludge & $+\mathrm{ve}$ & 3.366 & $62.33 \pm 0.13$ \\
\hline NAK17 & Kraft industry sludge & $+\mathrm{ve}$ & 3.184 & $63.68 \pm 0.18$ \\
\hline $\begin{array}{l}\text { Ralstonia eutropha } \\
\text { MTCC no. } 1473\end{array}$ & MTCC & $-\mathrm{ve}$ & 2.974 & $41.86 \pm 0.1$ \\
\hline
\end{tabular}

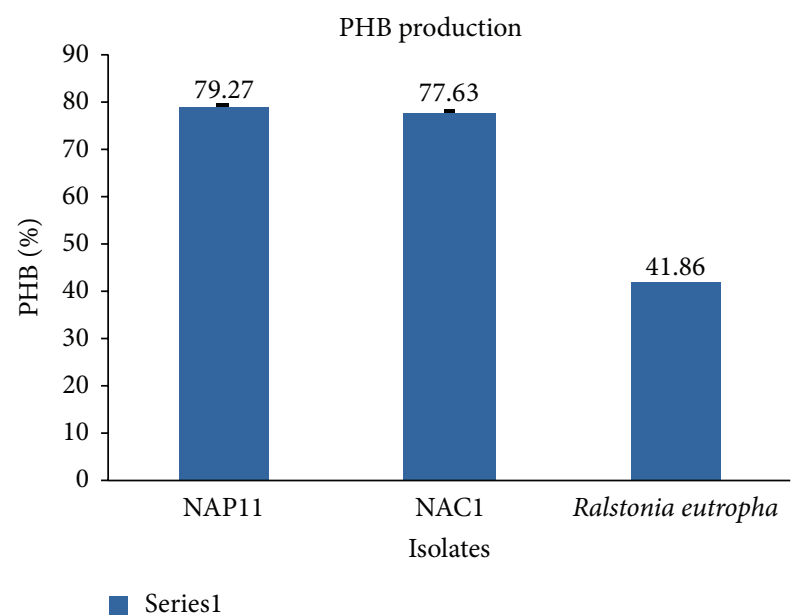

FIGURE 2: Comparison of PHB production from selected isolates with Ralstonia eutropha.

Enterococcus sp., and Brevundimonas sp., respectively. Other researchers also reported these genuses from the waste effluents. Silva et al. [33] studied the ecology of Enterococci and related bacteria in raw and treated waste water from a treatment plant receiving domestic and pretreated industrial effluents. The predominant species found in the raw waste water were Enterococcus hirae, Enterococcus faecium, and Enterococcus faecalis. Jiang et al. [34] isolated 3,851 in total Enterococci isolates from eight individual source categories including feces from animals and birds, soil, and sewage water samples to establish antibiotic resistance analysis (ARA). Reddy and Mohan [35] also reported the Enterococcus italicus sp. in mixed consortia in waste water treatment and produced
PHA up to $71.4 \%$. During their study of influence of substrate load and nutrient concentration (nitrogen and phosphorous) on PHA production using waste water as substrate and mixed culture as biocatalyst, they found that PHA accumulation was high at higher substrate load $(40.3 \%$ of dry cell weight (DCW)), low nitrogen (45.1\% DCW), and low phosphorous (54.2\% DCW) conditions by mixed consortia containg in Enterococcus sp. this paper confirms that Rani et al. [36] reported Brevundimonas with other bacteria as the dominant cultured bacteria in microbial diversity in functional pesticide effluent treatment plants (ETPs). Brevundimonas aveniformis sp.nov. A stalked species, was isolated from activated sludge by Ryu et al. [37]. Brevundimonas sp. MIFC and Brevundimonas diminuta was isolated from refinery active sludge and olive mill waste water, respectively, [38] and a Brevundimonas sp. were isolated from tannery waste treatment plant [39]. PHA production also reported up to $64 \%$ from the acid hydrolyzed saw dust (hydrolyzed wood) by Brevundimonas vesicularis. They also optimized the $\mathrm{C}: \mathrm{N}$ ratio for PHA production in Brevundimonas vesicularis $s p$. and found that $\mathrm{C}: \mathrm{N}$ proportion of $100: 3.5$ yielded maximum PHA up to $64 \%$ of cell dry weight. Thus, they concluded that acid hydrolyzed saw dust can be used as substrate by Brevundimonas vesicularis sp. for PHA production [40].

3.4. Polymer Analysis by ${ }^{1} H-N M R$ Spectroscopy. Based on the characterization of the PHA produced by NAP11 and NAC1 through NMR comparison with the standard PHB (Sigma), it was observed that the PHA obtained from NAP11 and NAC1 is having properties similar to that of the standard PHB (Sigma) (Figure 3(a)), so the PHA produced by both bacteria is polyhydroxybutyrate $(\mathrm{PHB})$. The structures of polyesters 


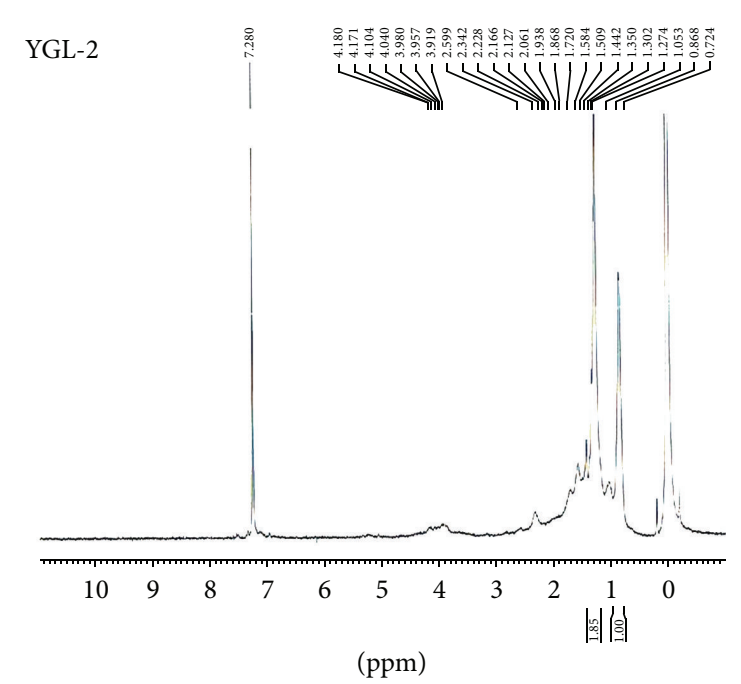

(a)

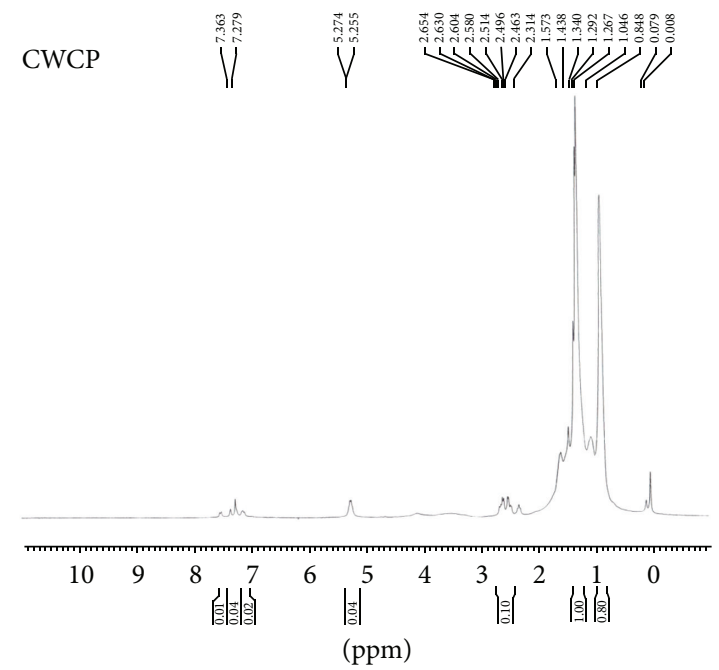

(b)

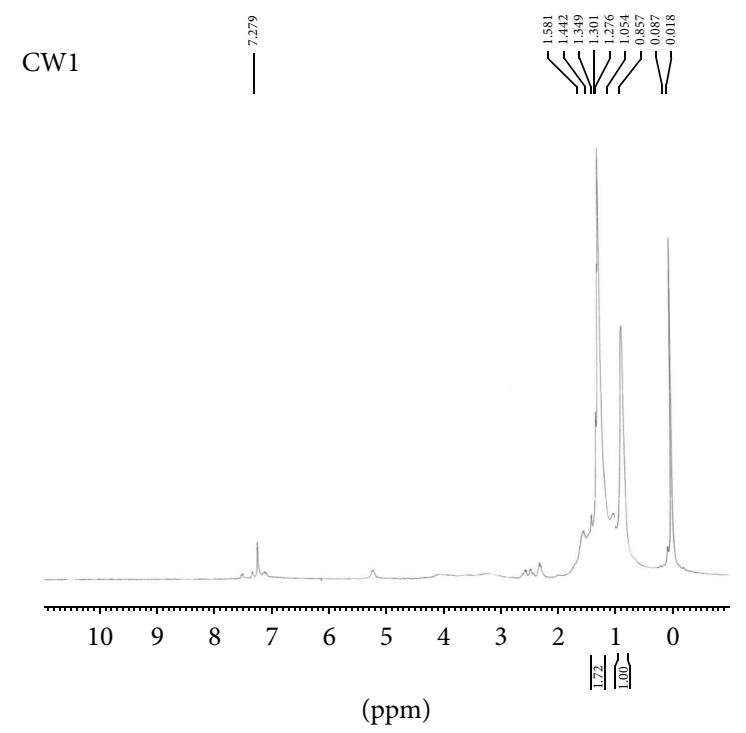

(c)

Figure 3: ${ }^{1}$ H NMR spectra of extracted PHB from isolates: (a) PHB standard (PHB Sigma Aldrich), (b) NAP11, and (c) NAC1.

were investigated by ${ }_{1} \mathrm{H}$ NMR. The ${ }_{1} \mathrm{H}$ NMR spectra of the PHAs extracted from Enterococcus sp. NAP11 show the following resonance signals: $\mathrm{HC}=\mathrm{CH}$ bond at $5.25 \mathrm{ppm}$, $\mathrm{CH}_{2} \mathrm{O}-\mathrm{COOH}$ bond at $2.580 \mathrm{ppm}$, a high signal at $1.26 \mathrm{ppm}$ that belongs to the hydrogen of methylene in the saturated lateral chain, and a terminal $-\mathrm{CH} 3$ group at $0.8 \mathrm{ppm}$; the ${ }_{1} \mathrm{H}$ NMR spectra (Figure 3(b)) of the PHAs extracted from Brevundimonas sp. NACl (Figure 3(c)) show the following resonance signals: $\mathrm{HC}=\mathrm{CH}$ bond at $5.30 \mathrm{ppm}, \mathrm{CH}_{2} \mathrm{O}-\mathrm{COOH}$ bond at $2.574 \mathrm{ppm}$, a high signal at $1.30 \mathrm{ppm}$ that belongs to the hydrogen of methylene in the saturated lateral chain, and a terminal $-\mathrm{CH} 3$ group at $0.857 \mathrm{ppm}$ [15]. The ${ }^{1} \mathrm{H}$ NMR spectra of the samples and the standard are almost identical, conferring that extracted intracellular compounds are polyhydroxybutyrates (PHBs).

3.5. Fourier Transform Infrared Spectroscopy (FTIR). Polymer extracted from NAP11 and NACl was used for recording IR spectra in the range $4000-600 \mathrm{~cm}^{-1}$. IR spectra (Figure 4) showed two intense absorption bands at 1720 and $1281 \mathrm{~cm}^{-1}$ of NAP11 and at 1720 and 1273 of NAC1 specific for $\mathrm{C}=\mathrm{O}$ and C-O stretching vibrations, respectively. The absorption bands at 2932 and $2954 \mathrm{~cm}^{-1}$ are due to C-H stretching vibrations of methyl, methylene groups. These prominent absorption bands confirm the structure of poly- $\beta$-hydroxybutyrate.

3.6. Thermogravimetric Analysis (TGA). TGA results of NAM5 showed that the $T_{m}$ is $171.33^{\circ} \mathrm{C}$ and the enthalpy of $\mathrm{PHA}$ fusion is $85.56 \mathrm{~J} / \mathrm{g}$. The result showed similarity with the data obtained from standard PHB $\left(176.29^{\circ} \mathrm{C}\right.$ and $\left.86.49 \mathrm{~J} / \mathrm{g}\right)$ [41] and from other studies from the literature also [42, 43].

3.7. GC-MS Analysis of Extracted PHA. In this study, the $\mathrm{PHB}$ was methanolysed in the presence of sulphuric acid and methanol, and the methanolysed $3 \mathrm{HB}$ was then analyzed 
TABLE 2: Morphological and biochemical characters of selected isolates.

\begin{tabular}{|c|c|c|}
\hline Morphological characters & NAP11 & NAC1 \\
\hline Colony color & White & Cream \\
\hline Colony texture & Smooth & Smooth-elevated \\
\hline Gram reaction & + ve & $-\mathrm{ve}$ \\
\hline Cell shape & Cocci-shaped & Rod-shaped \\
\hline Cell arrangement & Chain & Chain \\
\hline Spore formation & $-\mathrm{ve}$ & -ve \\
\hline \multicolumn{3}{|c|}{ Biochemical tests } \\
\hline Citrate utilization test & $-\mathrm{ve}$ & -ve \\
\hline Indole test & $+\mathrm{ve}$ & $+\mathrm{ve}$ \\
\hline Methyl red test & $-\mathrm{ve}$ & $-\mathrm{ve}$ \\
\hline V-P test & $-\mathrm{ve}$ & $-\mathrm{ve}$ \\
\hline $\mathrm{H}_{2} \mathrm{~S}$ production test & $+\mathrm{ve}$ & $+\mathrm{ve}$ \\
\hline Amylase production test & $-\mathrm{ve}$ & - ve \\
\hline Sucrose & $+\mathrm{ve}$ & $-\mathrm{ve}$ \\
\hline Dextrose & $+\mathrm{ve}$ & $+\mathrm{ve}$ \\
\hline Mannitol & $+\mathrm{ve}$ & $+\mathrm{ve}$ \\
\hline Trehalose & +ve & +ve \\
\hline D-Arabinose & $-\mathrm{ve}$ & $-\mathrm{ve}$ \\
\hline Maltose & $+\mathrm{ve}$ & $+\mathrm{ve}$ \\
\hline Glucose & $+\mathrm{ve}$ & $+\mathrm{ve}$ \\
\hline Raffinose & + ve & +ve with gas production \\
\hline Xylose & $-\mathrm{ve}$ & $-\mathrm{ve}$ \\
\hline Sorbitol & $-\mathrm{ve}$ & $-\mathrm{ve}$ \\
\hline Lactose & $-\mathrm{ve}$ & $-\mathrm{ve}$ \\
\hline Mannose & $-\mathrm{ve}$ & $-\mathrm{ve}$ \\
\hline Fructose & + ve & $-\mathrm{ve}$ \\
\hline Ribose & $-\mathrm{ve}$ & $-\mathrm{ve}$ \\
\hline Inulin & $-\mathrm{ve}$ & $-\mathrm{ve}$ \\
\hline Esculin & $-\mathrm{ve}$ & $-\mathrm{ve}$ \\
\hline Mellibiose & $-\mathrm{ve}$ & $-\mathrm{ve}$ \\
\hline Ramanose & -ve & $-\mathrm{ve}$ \\
\hline
\end{tabular}

by GC-MS. Figures 5(a) and 5(b) showed that a common molecular fragment of the $3 \mathrm{HB}$ methyl ester ion chromatogram of the PHB was produced. A predominant peak corresponding to the dimer $3 \mathrm{HB}$ methyl ester was noted at 13.63 to $13.667 \mathrm{~min}$, respectively, in GC purified product from NAP11 and NAC1, while 3 other major peaks were observed at $11.5,12.2$, and $12.3 \mathrm{~min}$. The retention times and ion fragment patterns of the peaks at 11.6 and $12.2 \mathrm{~min}$ were identical to those of the dimer methyl esters of $3 \mathrm{HV}$ and $3 \mathrm{HBV}$, respectively, but in very low percentage up to $5 \%$ in isolate NAP11 and $20 \%$ and $11 \%$ in NACl isolate, respectively. From the data obtained by GC-MS, the molecular weightof PHB obtained from isolate NAP11 is $256 \mathrm{kDa}$ and from isolate $\mathrm{NACl}$ is $242 \mathrm{kDa}$.

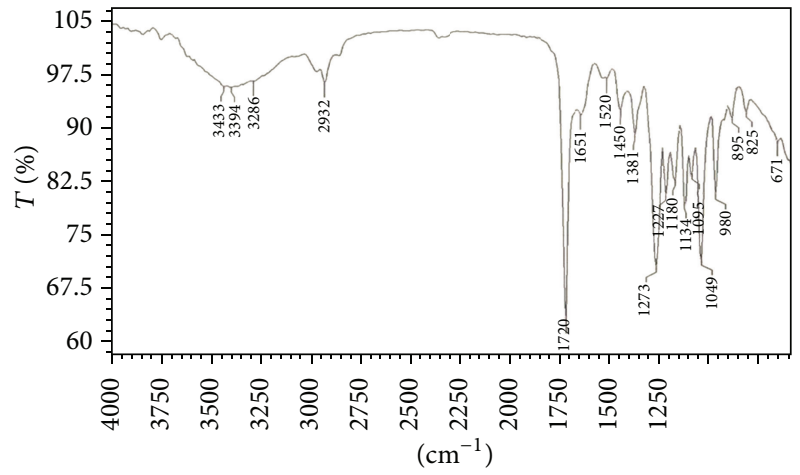

(a)

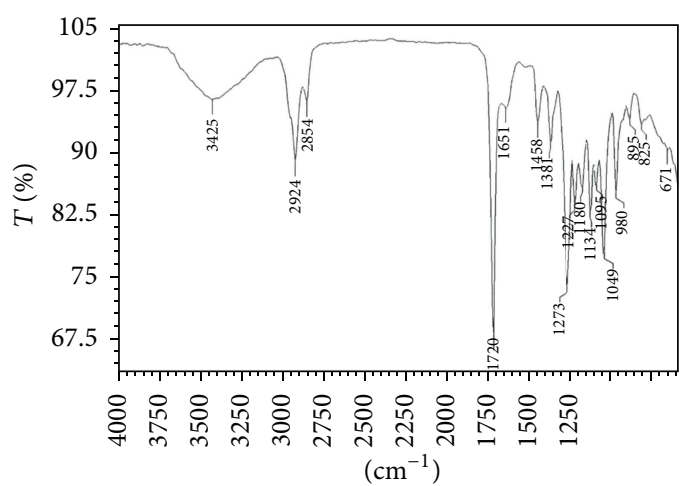

(b)

FIGURE 4: FTIR graph of extracted polymer of (a) NAP11 and (b) $\mathrm{NACl}$ isolates.

\section{Conclusion}

In this study, inexpensive cardboard industry waste water was tried as a carbon source to produce PHA. Different bacterial strains were isolated from cardboard industry waste water and pulp, kraft, and cardboard manufacturing industry sludge and screened for polyhydroxyalkanoate production using cardboard manufacturing industry waste water as a carbon source. The bacterial isolates NAP11 and NACl can be regarded as potential strains for the conversion of cardboard industry waste water into PHB. Both of the selected isolates utilized cardboard industry waste water as sole carbon source for growth and PHB biosynthesis, accumulating PHB up to $79.27 \%$ and $77.63 \%$ of the cell dry mass, respectively. As a conclusion, isolates NAP11 and NAC1 can be considered as good candidates for industrial production of PHB from cardboard industry waste water. Based on the morphological and biochemical characterization, NAP11 and NAC1 were identified up to genus level as Enterococcus sp. and Brevundimonas sp., respectively. Currently, these bacterial strains are further investigated to increase the productivity of PHB by the optimization of the process parameters and making the whole process more cost-effective.

\section{Conflict of Interests}

The authors declare that they have no competing interests. 


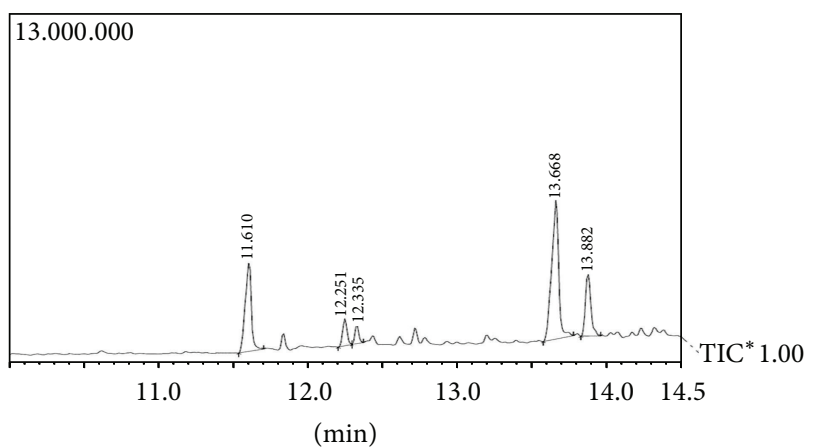

(a)

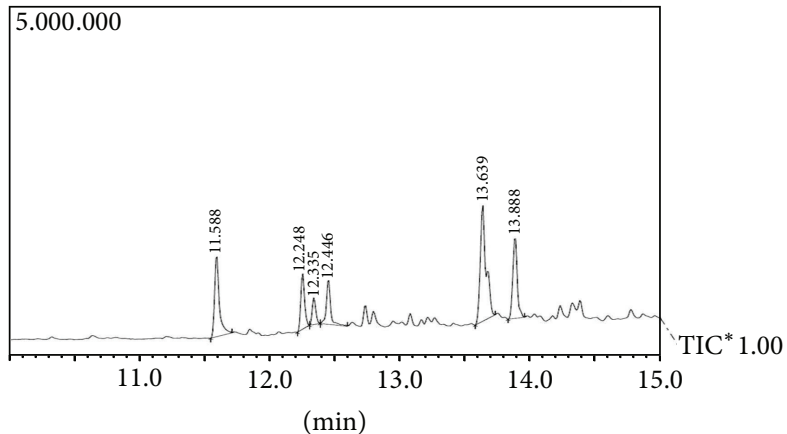

(b)

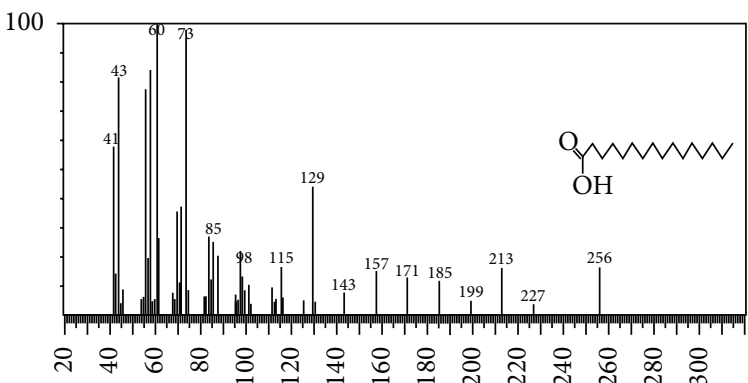

(c)

FIGURE 5: GC/MS analysis of poly(3HB) purified from NAP11 and NAC1 isolates. (a) GC of NAP11 showing main peak at 13.667 min of 3HB dimer. (b) GC of NACl showing main peak at 13.667 min of $3 \mathrm{HB}$ dimer and 3 other peaks indicating the presence of $3 \mathrm{HV}$ in the purified polymer. (c) MS graph showing that the major peak at $m / z 73$ is of hexadecanoic acid.

\section{Authors' Contribution}

All authors have made extensive contribution into the design, experiments and data analysis, paper preparation, and the review and finalization of this paper. All authors read and approved the final paper.

\section{Acknowledgments}

The authors express their sincere gratitude to the Rana cardboard industry, Yamuna Nagar, for providing the untreated waste water. The authors are very thankful to the Department of Chemistry, Kurukshetra University, Kurukshetra, India, for providing the necessary facilities for NMR analysis of the polymer.

\section{References}

[1] D. Byrom, "Polymer synthesis by microorganisms: technology and economics," Trends in Biotechnology, vol. 5, no. 9, pp. 246250, 1987.

[2] S. Y. Lee and H. N. Chang, "Production of poly(3-hydroxybutyric acid) by recombinant Escherichia coli strains: genetic and fermentation studies," Canadian Journal of Microbiology, vol. 41, no. 1, pp. 207-215, 1995.

[3] B. Hazer and A. Steinbüchel, "Increased diversification of polyhydroxyalkanoates by modification reactions for industrial and medical applications," Applied Microbiology and Biotechnology, vol. 74, no. 1, pp. 1-12, 2007.
[4] X. Gao, J. Chen, Q. Wu, and G. Chen, "Polyhydroxyalkanoates as a source of chemicals, polymers, and biofuels," Current Opinion in Biotechnology, vol. 22, no. 6, pp. 768-774, 2011.

[5] E. Rudnik, "Definitions, structures and methods of preparation," in Compostable Polymer Materials, pp. 10-36, Elsevier, Amsterdam, The Netherlands, 1st edition, 2008.

[6] J. Choi and S. Y. Lee, "Process analysis and economic evaluation for poly(3-hydroxybutyrate) production by fermentation," Bioprocess Engineering, vol. 17, no. 6, pp. 335-342, 1997.

[7] I. M. Tamer, M. Moo-Young, and Y. Chisti, "Optimization of poly( $\beta$-hydroxybutyric acid) recovery from Alcaligenes latus: combined mechanical and chemical treatments," Bioprocess Engineering, vol. 19, no. 6, pp. 459-468, 1998.

[8] E. Grothe, M. Moo-Young, and Y. Chisti, "Fermentation optimization for the production of poly $(\beta$-hydroxybutyric acid) microbial thermoplastic," Enzyme and Microbial Technology, vol. 25, no. 1-2, pp. 132-141, 1999.

[9] T. Yamane, "Cultivation engineering of microbial bioplastics production," FEMS Microbiology Reviews, vol. 103, no. 2-4, pp. 257-264, 1992.

[10] T. Yamane, "Yield of poly-D(-)-3-hydroxybutyrate from various carbon sources: a theoretical study," Biotechnology and Bioengineering, vol. 41, no. 1, pp. 165-170, 1993.

[11] P. M. Halami, "Production of polyhydroxyalkanoate from starch by the native isolate Bacillus cereus CFR06," World Journal of Microbiology and Biotechnology, vol. 24, no. 6, pp. 805-812, 2008. 
[12] L. R. Castilho, D. A. Mitchell, and D. M. G. Freire, "Production of polyhydroxyalkanoates (PHAs) from waste materials and byproducts by submerged and solid-state fermentation," Bioresource Technology, vol. 100, no. 23, pp. 5996-6009, 2009.

[13] M. L. Juan, L. W. Gonzalez, and G. C. Walker, "A novel screening method for isolating exopolysaccharide-deficient mutants," Applied and Environmental Microbiology, vol. 64, no. 11, pp. 4600-4602, 1998.

[14] P. Spiekermann, B. H. A. Rehm, R. Kalscheuer, D. Baumeister, and A. Steinbüchel, "A sensitive, viable-colony staining method using Nile red for direct screening of bacteria that accumulate polyhydroxyalkanoic acids and other lipid storage compounds," Archives of Microbiology, vol. 171, no. 2, pp. 73-80, 1999.

[15] G. Singh, A. Mittal, A. Kumari, V. Goel, N. K. Aggarwal, and A. Yadav, "Optimization of poly-B-hydroxybutyrate production from Bacillus species," European Journal of Biological Sciences, vol. 3, no. 4, pp. 112-116, 2011.

[16] J. Law and R. A. Slepecky, "Assay of poly-beta-hydroxybutyric acid," Journal of Bacteriology, vol. 82, pp. 52-55, 1961.

[17] I. Y. Lee, H. N. Chang, and Y. H. Park, "A simple method for recovery of microbial poly-3-hydroxybutyrate by alkaline solution treatment," Journal of Microbiology and Biotechnology, vol. 5, no. 4, pp. 238-240, 1995.

[18] G. Du, J. Chen, J. Yu, and S. Lun, "Continuous production of poly-3-hydroxybutyrate by Ralstonia eutropha in a two-stage culture system," Journal of Biotechnology, vol. 88, no. 1, pp. 5965, 2001.

[19] M. R. Zakaria, H. J. Ariffin, N. A. M. Aziz, S. A. Nishida, H. Y. Shirai, and M. A. Hassan, "Biosynthesis and characterization of poly(3-hydroxybutyrate-co-3- hydroxyvalerate) copolymer from wild-type Comamonas sp. EB172," Polymer Degradation and Stability, vol. 95, no. 8, pp. 1382-1386, 2010.

[20] A. Steinbüchel, "Perspectives for biotechnological production and utilization of biopolymers: metabolic engineering of polyhydroxyalkanoats biosynethesis pathways as a successful example," Macromolecular Bioscience, vol. 1, pp. 1-24, 2001.

[21] M. Zinn, B. Witholt, and T. Egli, "Occurrence, synthesis and medical application of bacterial polyhydroxyalkanoate," Advanced Drug Delivery Reviews, vol. 53, no. 1, pp. 5-21, 2001.

[22] J. Teeka, T. Imai, X. Cheng et al., "Screening of PHA producing bacteria using biodiesel-derived waste glycerol as a sole carbon source," Journal of Water and Environment Technology, vol. 8, pp. 371-381, 2010.

[23] H. Ramachandran and A. A. Abdullah, "Isolation of PHAproducing bacteria from Malaysian environment," in Proceedings of the 7th IMT-GT UNINET and the 3rd International PSUUNS Conferences on Bioscience, pp. 178-179, 2010.

[24] S. Kitamura and Y. Doi, "Staining method of poly(3-hydroxyalkanoic acids) producing bacteria by nile blue," Biotechnology Techniques, vol. 8, no. 5, pp. 345-350, 1994.

[25] K. Cho, H. W. Ryu, C. Park, and P. R. Goodrich, "Poly(hydroxybutyrate-co-hydroxyvalerate) from swine waste liquor by Azotobacter vinelandii UWD," Biotechnology Letters, vol. 19, no. 1, pp. 7-10, 1997.

[26] J. Yu, "Production of PHA from starchy wastewater via organic acids," Journal of Biotechnology, vol. 86, no. 2, pp. 105-112, 2001.

[27] H. Salehizadeh and M. C. M. van Loosdrecht, "Production of polyhydroxyalkanoates by mixed culture: recent trends and biotechnological importance," Biotechnology Advances, vol. 22, no. 3, pp. 261-279, 2004.
[28] J. M. L. Dias, P. C. Lemos, L. S. Serafim et al., "Recent advances in polyhydroxyalkanoate production by mixed aerobic cultures: from the substrate to the final product," Macromolecular Bioscience, vol. 6, no. 11, pp. 885-906, 2006.

[29] N. Ceyhan and G. Ozdemir, "Poly- $\beta$-hydroxybutyrate (PHB) production from domestic wastewater using Enterobacter aerogenes 12Bi strain," African Journal of Microbiology Research, vol. 5, no. 6, pp. 690-702, 2011.

[30] K. J. Ganzeveld, A. Van Hagen, M. H. Van Agteren, W. De Koning, and A. J. M. S. Uiterkamp, "Upgrading of organic waste: production of the copolymer poly-3-hydroxybutyrateco-valerate by Ralstonia eutrophus withorganic waste as sole carbon source," Journal of Cleaner Production, vol. 7, no. 6, pp. 413-420, 1999.

[31] M. N. Rao and A. K. Datta, Waste Water Treatment, pp. 203-208, Oxford and IBH Publishing, New Delhi, India, 2007.

[32] G. H. John, N. R. Krieg, S. Peter, H. A. Staley, T. W. Satnley, and T. James, Bergey's Manual of Determinative Bacteriology, Williams and Wilkins, Philadelphia, Pa, USA, 9th edition, 2009.

[33] M. F. da Silva, I. Tiago, A. Veríssimo, R. A. Boaventura, O. C. Nunes, and C. M. Manaia, "Antibiotic resistance of Enterococci and related bacteria in an urban wastewater treatment plant," FEMS Microbiology Ecology, vol. 55, no. 2, pp. 322-329, 2005.

[34] S. C. Jiang, W. Chu, B. H. Olson et al., "Microbial source tracking in a small southern California urban watershed indicates wild animals and growth as the source of fecal bacteria," Applied Microbiology and Biotechnology, vol. 76, no. 4, pp. 927-934, 2007.

[35] M. V. Reddy and S. V. Mohan, "Effect of substrate load and nutrients concentration on the polyhydroxyalkanoates (PHA) production using mixed consortia through wastewater treatment," Bioresource Technology, vol. 114, pp. 573-582, 2011.

[36] A. Rani, S. Porwal, R. Sharma, A. Kapley, H. J. Purohit, and V. C. Kalia, "Assessment of microbial diversity in effluent treatment plants by culture dependent and culture independent approaches," Bioresource Technology, vol. 99, no. 15, pp. 70987107, 2008.

[37] S. H. Ryu, M. Park, J. R. Lee, P. Yun, and C. O. Jeon, "Brevundimonas aveniformis sp. nov., a stalked species isolated from activated sludge," International Journal of Systematic and Evolutionary Microbiology, vol. 57, no. 7, pp. 1561-1565, 2007.

[38] C. Ruggeri, A. Franzetti, G. Bestetti et al., "Isolation and characterisation of surface active compound-producing bacteria from hydrocarbon-contaminated environments," International Biodeterioration and Biodegradation, vol. 63, no. 7, pp. 936-942, 2009.

[39] G. Tsiamis, G. Tzagkaraki, A. Chamalaki et al., "Olive-mill wastewater bacterial communities display a cultivar specific profile," Current Microbiology, vol. 64, no. 2, pp. 197-203, 2012.

[40] J. A. Silva, L. M. Tobella, J. Becerra, F. Godoy, and M. A. Martínez, "Biosynthesis of poly- $\beta$-hydroxyalkanoate by Brevundimonas vesicularis LMG P-23615 and Sphingopyxis macrogoltabida LMG 17324 using acid-hydrolyzed sawdust as carbon source," Journal of Bioscience and Bioengineering, vol. 103, no. 6, pp. 542-546, 2007.

[41] V. Tanamool, T. Imai, P. Danvirutai, and P. Kaewkannetra, "Biosynthesis of polyhydroxyalkanoate (PHA) by Hydrogenophaga sp. Isolated from soil environment during batch fermentation," Journal of Life Sciences, vol. 5, no. 12, pp. 10031012, 2011.

[42] A. Yezza, A. Halasz, W. Levadoux, and J. Hawari, "Production of poly- $\beta$-hydroxybutyrate (PHB) by Alcaligenes latus from maple 
sap," Applied Microbiology and Biotechnology, vol. 77, no. 2, pp. 269-274, 2007.

[43] W. M. Pachekoski, J. A. M. Agnelli, and L. P. Belem, "Thermal, mechanical and morphological properties of poly (hydroxybutyrate) and polypropylene blends after processing," Materials Research, vol. 12, no. 2, pp. 159-164, 2009. 

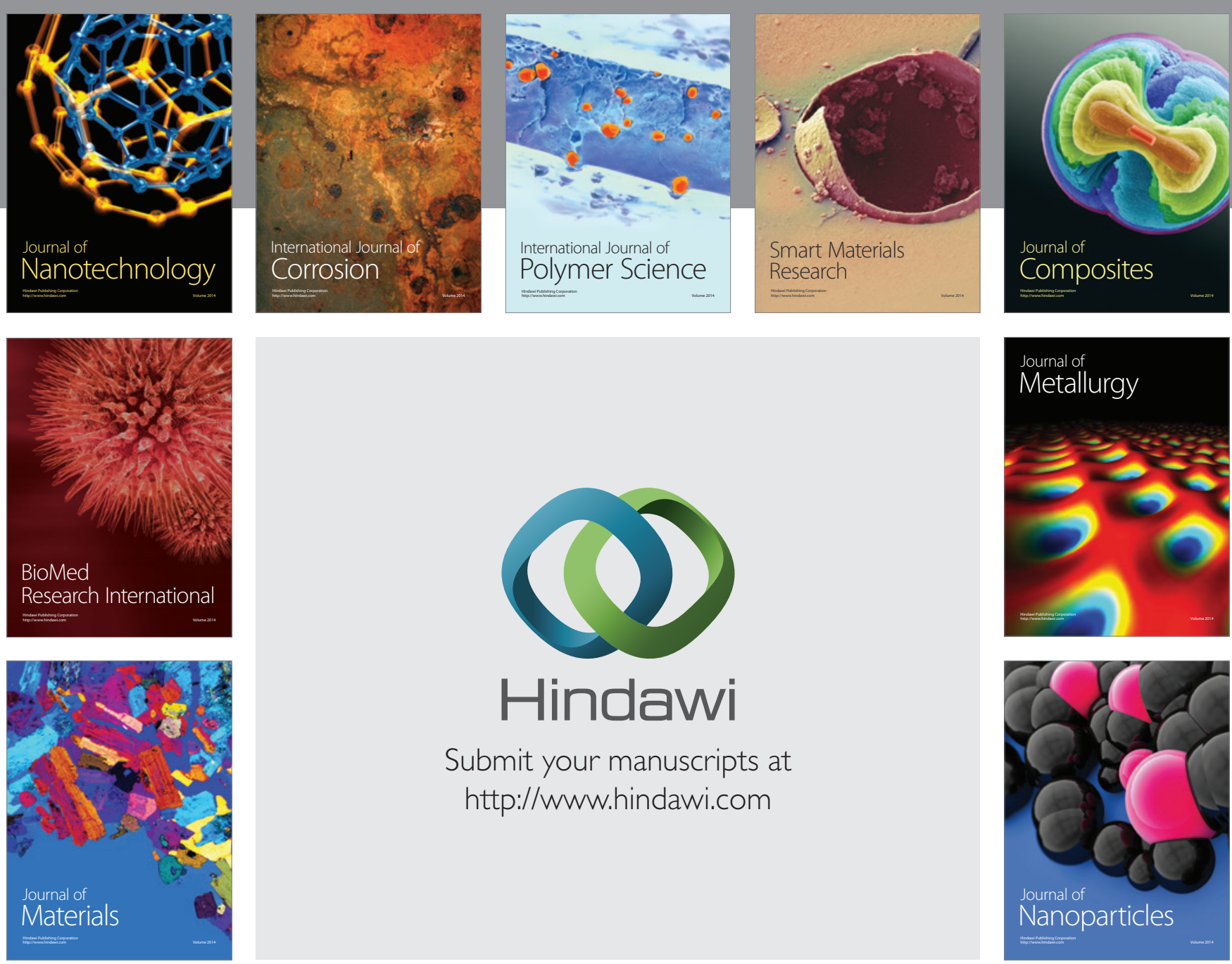

Submit your manuscripts at http://www.hindawi.com
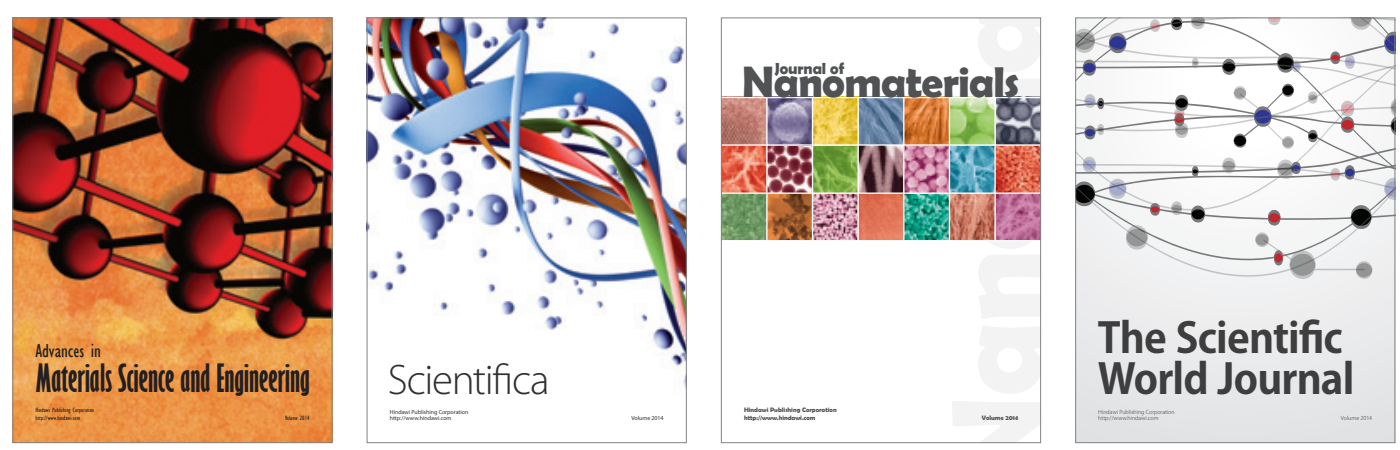

\section{The Scientific World Journal}
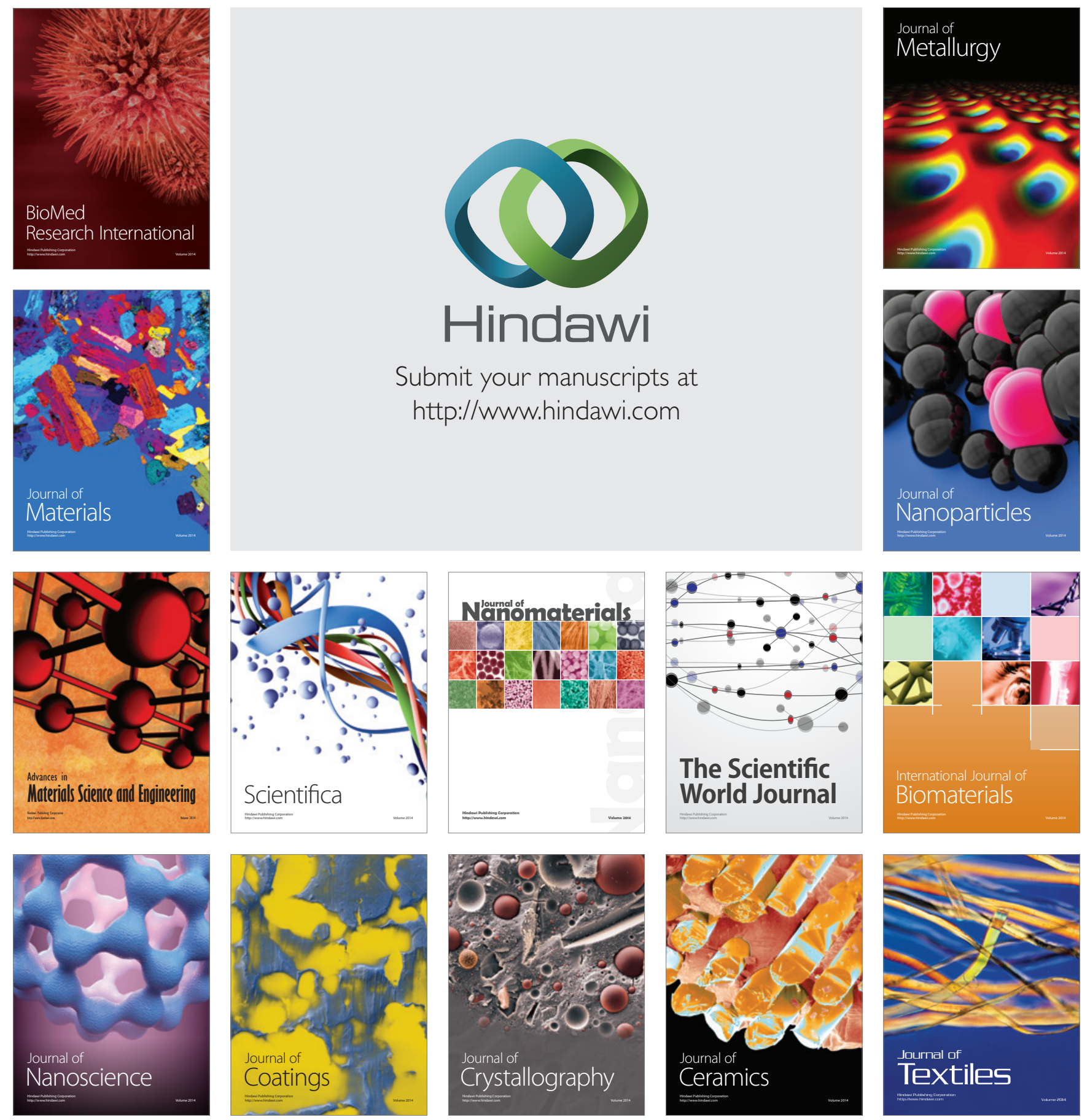